\title{
Correction to: Fucosidosis
} in Tunisian patients: mutational analysis and homology-based modeling of FUCA1 enzyme

\author{
Latifa Chkioua ${ }^{*}$, Yessine Amri ${ }^{2}$, Sahli Chaima ${ }^{2}$, Ferdawes Fenni ${ }^{1}$, Hela Boudabous ${ }^{3}$, Hadhami Ben Turkia ${ }^{3}$, \\ Taieb Messaoud ${ }^{2}$, Neji Tebib ${ }^{3}$ and Sandrine Laradi ${ }^{4}$
}

\section{Correction to: BMC Med Genomics (2021) 14:208}

https://doi.org/10.1186/s12920-021-01061-3

Following publication of the original article [1], the authors identified an error in the author name of Sahli Chaima.

The incorrect author name is:

Chayma (given name) Saheli (family name)

The correct author name is:

Sahli (given name) Chaima (family name)

The author group has been updated above and the original article [1] has been corrected.

\section{Author details}

${ }^{1}$ Research Laboratory of Human Genome and Multifactorial Diseases, Faculty of Pharmacy, University of Monastir, Street Avicenne, 5000 Monastir, Tunisia. ${ }^{2}$ Biochemistry Laboratory (LR 00SP03), Bechir Hamza Children's Hospital, Tunis, Tunisia. ${ }^{3}$ Pediatrics Department, La Rabta Hospital, Tunis, Tunisia. ${ }^{4}$ The Auvergne-Rhône-Alpes Regional Branch of the French National Blood System EFS/GIMAP-EA 3064, 42100 Saint Etienne, France.

Published online: 15 December 2021

The original article can be found online at https://doi.org/10.1186/s12920021-01061-3.

*Correspondence: chkioualatifa2002@yahoo.fr

${ }^{1}$ Research Laboratory of Human Genome and Multifactorial Diseases,

Faculty of Pharmacy, University of Monastir, Street Avicenne,

5000 Monastir, Tunisia

Full list of author information is available at the end of the article

\author{
Reference \\ 1. Chkioua L, Amri Y, Chaima S, et al. Fucosidosis in Tunisian patients: \\ mutational analysis and homology-based modeling of FUCA1 \\ enzyme. BMC Med Genomics. 2021;14:208. https://doi.org/10.1186/ \\ s12920-021-01061-3.
}

\section{Publisher's Note}

Springer Nature remains neutral with regard to jurisdictional claims in published maps and institutional affiliations.

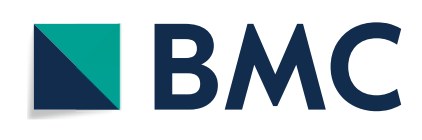

(c) The Author(s) 2021. Open Access This article is licensed under a Creative Commons Attribution 4.0 International License, which permits use, sharing, adaptation, distribution and reproduction in any medium or format, as long as you give appropriate credit to the original author(s) and the source, provide a link to the Creative Commons licence, and indicate if changes were made. The images or other third party material in this article are included in the article's Creative Commons licence, unless indicated otherwise in a credit line to the material. If material is not included in the article's Creative Commons licence and your intended use is not permitted by statutory regulation or exceeds the permitted use, you will need to obtain permission directly from the copyright holder. To view a copy of this licence, visit http://creativecommons.org/licenses/by/4.0/. The Creative Commons Public Domain Dedication waiver (http://creativeco $\mathrm{mmons}$.org/publicdomain/zero/1.0/) applies to the data made available in this article, unless otherwise stated in a credit line to the data. 